\title{
The Irony of Flood Risks in African Dryland Environments: Human Security in North Cameroon
}

\author{
Henry Bang, Lee Miles, Richard Gordon \\ Disaster Management Centre, Faculty of Management, Bournemouth University, Bournemouth, United Kingdom \\ Email: hbang@bournemouth.ac.uk,1miles@bournemouth.ac.uk, rgordon@bournemouth.ac.uk
}

How to cite this paper: Bang, H., Miles, L. and Gordon, R. (2017) The Irony of Flood Risks in African Dryland Environments: Human Security in North Cameroon. World Journal of Engineering and Technology, 5, 109-121.

https://doi.org/10.4236/wjet.2017.53B013

Received: July 26, 2017

Accepted: August 8, 2017

Published: August 11, 2017

\begin{abstract}
North Cameroon, though located in an arid environment, ironically also suffers from the serious threat of flooding in the region. This article examines contemporary challenges resulting from frequent flooding in North Cameroon. Using Cutter's "Hazard of Place Model" of vulnerability as the conceptual basis, the article triangulates data from a variety of sources to analyze environmental risks, social and biophysical vulnerability and flood impact, including flood risk management in North Cameroon. The findings reveal that North Cameroon is vulnerable to frequent flooding due to a combination of environmental, socio-economic, and geographic factors further compounded by low organizational resilience to flooding with dire consequences for livelihoods. We argue that, if not handled appropriately, the impact of flooding in North Cameroon risks trapping the population in a permanent and vicious cycle of destitution and poverty. The government urgently needs to review its disaster management policies to be more proactive and strategic in flood management in order to enhance human security and prevent permanent damage to the livelihoods and the micro-economy of the region. Lessons learned from this research, when applied, can help to reduce the vulnerabilities of the poverty-stricken population and enhance resilience to flood risks.
\end{abstract}

\section{Keywords}

Frequent Flooding, North Cameroon, Vulnerability, Flood Management

\section{Introduction}

All over the world people are wary of severe wet weather. Flooding is frequently highlighted as the Earth's most common, destructive and most deadly natural 
hazard. Moreover, the impact of flood damage/loss continues to rise worldwide affecting natural, social, human, physical and social capital; with developing countries hit hardest [1]. At a time when the world is experiencing big advances in scientific and technological innovation in natural hazard/disaster prediction and mitigation the international community, led by the United Nations International Strategy for Disaster Reduction (UN ISDR), still struggles to understand why these rising consequences of natural hazards/disasters especially floods, have not been matched by necessary Disaster Risk Reduction (DRR) strategies within member states [2].

Flood management is at the top of many government agendas as a result of climate research that suggests that the number of days of extremely heavy rainfall is rising by between $1 \%$ to $2 \%$ each decade; thereby contributing to an increase in the frequency and intensity of floods worldwide [3]. Projections also indicate that, over the next few decades, increasing rainfall will lead to more flooding, with Climate Change (CC) further exacerbating extreme weather events (IPCC, 2014). This will have a greater impact on the communities and governments of developing countries because of their limited resources and inadequate infrastructures to mitigate, prepare and respond to flooding, making them more vulnerable to future shocks [4] [5].

Flooding is a common phenomenon in Cameroon, and has become catastrophic in recent decades, affecting more than 373, 176 people between 2000 and 2015 with an increasing death toll and dire ramifications for livelihoods [6]. Even arid north Cameroon is not exempt from flooding. Heavy rainfall in recent decades has been causing annual flash floods in North Cameroon. Drought prone thirsty soils have occasionally become super-saturated with water, flooding extensive areas often with devastating consequences to livelihoods and the agrarian economy.

Since flash flooding is a seasonal phenomenon in several parts of Cameroon, just as in many developing countries, its impact on rural communities and livelihoods is often ignored, not investigated and often not documented [7]. However, the cumulative impact of small-scale disasters on the livelihoods of vulnerable communities is not properly monitored and can ultimately damage a country's economy. Using North Cameroon as an example, this article seeks to highlight vulnerabilities to flooding, and the ramifications of frequent flooding on local livelihoods. The aim is to make a novel contribution to the literature of frequent flooding in dry land environments, contribute to knowledge in this area and inform flood policy for improved flood risk mitigation in Cameroon and other developing countries facing a similar scenario.

\section{Conceptual Framework}

The analysis of repeated flooding in North Cameroon, presented in this article, adopts social and physical vulnerability dimensions affecting the discussion of disasters triggered by environmental events. Although hugely influenced by en- 
vironmental factors, weaknesses in the human system, specifically the social conditions in which people live, are key triggers of such disasters [8]. This is captured in the "Hazard of Place" model of vulnerability [9] [10] that seeks to integrate the underlying social and biophysical elements that contribute to vulnerability into the vulnerability of place. This point of view is conveyed in the modified 'Hazard of Place' model (see Figure 1) that shows the interaction between an environmental condition and vulnerable social and physical/geographic conditions that produce a potential hazard of flooding. The feedback loops in the model attempt to show the interactions and links to the major components of a disaster in a cause-effect chain, and indicates the role of government to mitigate vulnerability. The modified "Hazard of Place" model summarizes all the key elements of the study as integrated in the findings. The hypothesis is that flood risks in North Cameroon are mainly a function of severe weather, which interact with vulnerable social/physical conditions in the region in a particular geographic context (relief and drainage) amidst low organisational resilience to flooding.

\section{Environmental Risk}

Contemporary CC research has revealed that anthropogenic activities, over several decades, have resulted in higher temperatures. This trend is predicted to continue with average sea temperatures increasing from $1.50^{\circ} \mathrm{C}$ to $4.50^{\circ} \mathrm{C}$ by 2100. The subsequent climate variation (CV), or altering of natural variations in the Earth's climate, is leading to an increased frequency in, and intensity of, rainfall [5]. Such an impact from climate variation is being particularly felt in Cameroon, where mean annual temperatures have increased by an average of $0.15^{\circ} \mathrm{C}$ per decade [11] with predictions that the average annual rainfall could increase by as much as $35 \%$ between 2010 and 2050 [12].

Cameroon is prone to several natural hazards (volcanic eruptions, earth-

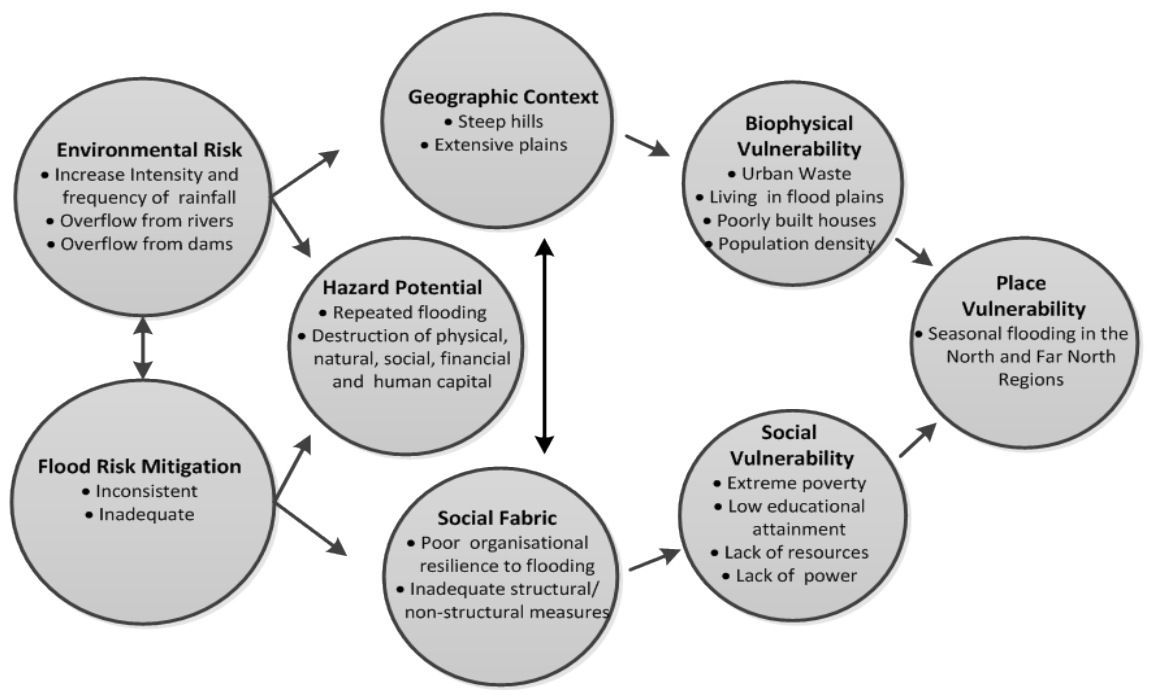

Figure 1. Hazard of Place model of vulnerability. Source, Authors, adapted from [9]. 
quakes, landslides, toxic gas eruptions from crater lakes) with floods being the most frequent and most damaging (Bang, 2016). CV has caused an increase in the frequency and intensity of flash floods in recent years with increased damages to property, livelihoods and fatalities [13] [14] [15] [16].

\section{Methodology}

\subsection{Case Study Strategy}

This research adopted a case study strategy, with the focus on Garoua, a town in North Cameroon that has been experiencing annual flooding. The research is qualitative, exploratory and descriptive and is based on multiple sources of evidence including empirical and secondary data, knowledge/experience and inferences about the hazard phenomenon that is contextualized. There was an intensive search for documentary evidence from various sources including books, journals, newspaper articles, official documents and NGO reports etc. on the issues under investigation. Eight interviews were conducted in February/March 2017 with senior Cameroon disaster management officials to understand amongst other issues, vulnerability and organizational resilience to flood and disaster management in Cameroon [17] [18] [19]. These strategies have informed the findings of the research.

\subsection{Case Study Site}

The case study site, Garoua, is the economic and administrative capital of the North Region, and the most densely populated town in Cameroon (see Figure 2) [20]. Garoua is host to several industries and agricultural parastatals that in

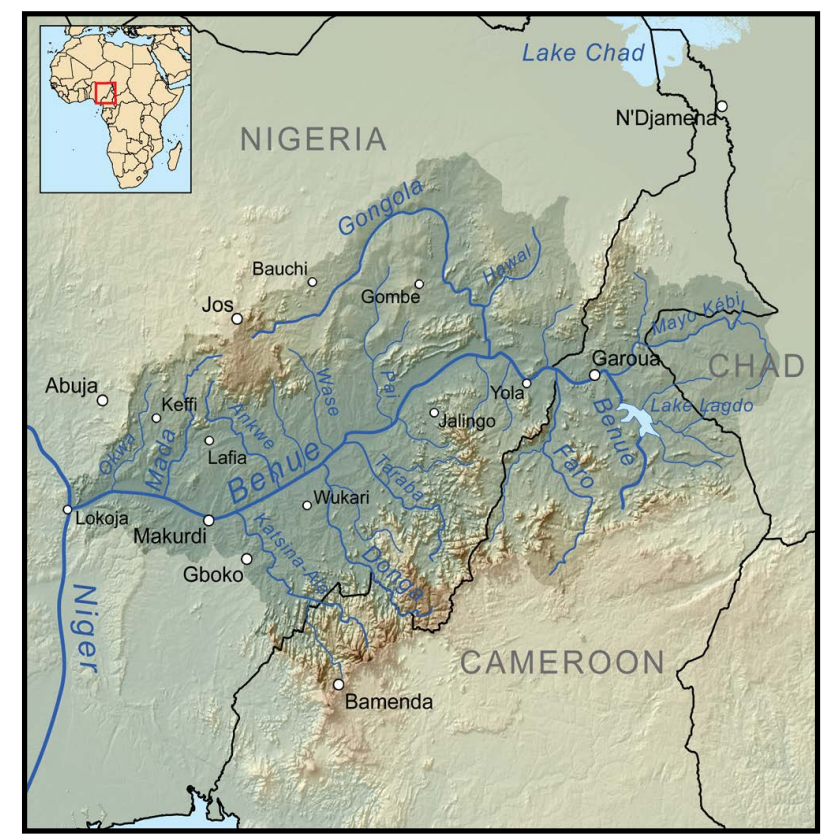

Figure 2. Map of Cameroon showing Garoua town, River Benue, The drainage, Lagdo Dam and Relief. 
fluence the region's economy [21] [22]. The town is also a port city along River Benue, which meanders on an extensive floodplain and dominates the drainage system. Eighty kilometres from Garoua, on the River Benue, is the Lagdo Dam, which has a capacity of 620 million cubic meters [23].

\section{Main Findings}

\subsection{Hazard Potential}

Cameroon's Northern region, though located in an arid environment, has been experiencing recurring annual flash floods in recent years, and disaster managers are worried that this is now a regular trend. Prominent flood events occurred in 1988, 1989, 1999, 2001, 1994, 1995, 1996, 1998, 2010, 2011, 2012, 2013, 2014 and 2015, usually with socio-economic and environmental consequences (see Table 1). In the 1999 and 2012 floods, the Lagdo and Maga dams were seriously affected, forcing water to be released from the reservoir, which in turn exacerbated the flooding downstream. Urban areas usually suffer the brunt of these floods,

Table 1. Major flooding in Cameroon from 1988-2015.

\begin{tabular}{|c|c|c|}
\hline Year & Location & Effects \\
\hline 1988-1989 & Northern Cameroon & $\begin{array}{l}\text { 51deaths, Houses destroyed and 58,000 people affected } \\
\text { Thousands of hectares of cereal farms destroyed }\end{array}$ \\
\hline 1991 & Maroua & 2 deaths and about 200 people displaced \\
\hline 1994 & Maroua, Mokolo, Logone\& Chari & 6 deaths \\
\hline 1999 & $\begin{array}{c}\text { Garoua, Demsa, Pitoa, Padang, Bame, } \\
\text { Pabla, Dargala and Taipee }\end{array}$ & $\begin{array}{l}24 \text { deaths and about } 1000 \text { homeless } \\
\text { Lagdo dam and other infrastructures damaged }\end{array}$ \\
\hline 2000 & Maroua & $\begin{array}{l}4 \text { deaths and thousands of households affected } \\
\text { Bridges, Houses destroyed }\end{array}$ \\
\hline 2001 & Maroua & 2 deaths \\
\hline 2008 & Garoua and 27 Neighbourhoods & $\begin{array}{l}\rightarrow \text { deaths, } 5000 \text { affected, } 80 \% \text { of cultivated land in } \\
\text { Garoua destroyed, including bridges and roads } \\
\text { Respiratory infections, malaria, diarrhoea and cholera } \\
\text { More than } 113 \text { deaths, and } 600 \text { families left homeless }\end{array}$ \\
\hline 2010 & Pouss & $\begin{array}{l}1000 \text { hectares of crops and } 300 \text { houses destroyed } \\
\text { Caused cholera epidemic, diarrhoea, malaria }\end{array}$ \\
\hline 2011 & Garoua & Affected thousands and caused cholera outbreak \\
\hline 2012 & $\begin{array}{c}\text { Garoua, Maga, Doreissou, } \\
\text { Begué, Palam, Dougui, Pouss and Tekele }\end{array}$ & $\begin{array}{l}\text { More than } 30 \text { fatalities, } 150,000 \text { affected and } \\
\text { Thousands of hectares of cereal farms were destroyed } \\
\text { Infrastructure, and crops damaged worth billions of CFA } \\
\text { Hydrological structures (dams, dykes) damaged } \\
\text { Caused delay in the start of the } 2012 / 2013 \text { school year }\end{array}$ \\
\hline 2013 & Dongui, Kaikai in Far North Region & $\begin{array}{l}\text { Rupture of dam along Logone river } \\
\text { Evacuations of people along the Magda dam } \\
\quad 9000 \text { people displaced }\end{array}$ \\
\hline 2015 & $\begin{array}{l}\text { Maroua, Gazawa, Bogo. Ndamare, } \\
\text { Ndoukoula district }\end{array}$ & $\begin{array}{l}3 \text { deaths } \\
94 \text { houses damaged }\end{array}$ \\
\hline
\end{tabular}

Source: Authors, compiled from various sources including, 1988 Global Register of Extreme Flood Events, [24] [27] [28] [29]. 
mainly due to problems caused by urbanization, such as settlements in marshy areas and high population growth [24]. According to Cameroon's Department of Civil Protection (DCP) the central agency responsible for coordinating and managing disasters in the country, the worst flooding in Northern Cameroon for more than 60 years occurred in 2012 [25] [26]. The ramifications of the 2012 flooding in Garoua have been analyzed in section 5.4.

\subsection{Social Vulnerability}

Social and economic conditions influencing the lives of inhabitants in North Cameroon also make them vulnerable to flooding. First, the population of North Cameroon is the poorest in the country. Poverty indices of the North Region (49\%) and Far North Regions (44\%) are the highest in the country [30] [31]. Interview transcripts reveal the main reason for this high poverty is a lack of diversification in livelihoods, keeping the population solely reliant on subsistence rain-fed agriculture that is now threatened from frequent flooding.

Second, Garoua is one of the most densely populated towns in Cameroon, located in a highly populated region of the country [32]. Over the years, due to poverty and food insecurity, the extensive flood plains of River Benue, have attracted many local indigenes, including refugees fleeing the crisis in the Central African Republic, and the Boko Haram insurgency in Northern Nigeria [33]. This has caused a dramatic increase in population density [34] as well as an increase in agrarian activities causing land degradation and/or soil erosion, which in turn exacerbates flooding [23] [24].

Third, the Boko Haram insurgency in Nigeria has crossed into North Cameroon, causing insecurity and fear [35]. Government officials attest to the fact that the local population in the region is traumatized by constant attacks, including deaths and abductions of local residents, perpetrated by the terrorists. The consequence is that many families have fled for safety thereby weakening the social cohesion in the region [33]. High levels of poverty and weak social networks thus reduce greatly local coping capacities and the ability to recover from natural hazards [8].

Fourth, the region is prone to health risks exacerbated by frequent flooding. Water-borne diseases like malaria cause between $35 \%$ and $40 \%$ of all deaths in North Cameroon [36] [37]. In addition, the rate of malnutrition is over $44 \%$, the highest in Cameroon [38] [39]. Poor health diverts scarce medical resources. This cost to human capital and financial resources, reduces the ability and capacity of local inhabitants to engage fully in flood mitigation measures [40].

\subsection{Biophysical Vulnerability}

The location of dwellings, and the durability/strength of the buildings, determines susceptibility to flooding. Due to poverty, many Garoua city slum dwellers have built their houses in flood prone or poorly drained areas close to River Benue and its tributaries as shown in Figure 2(a). Moreover, many of these 


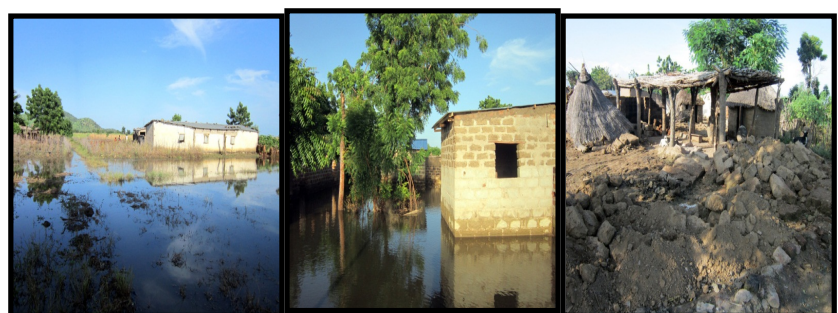

(a)

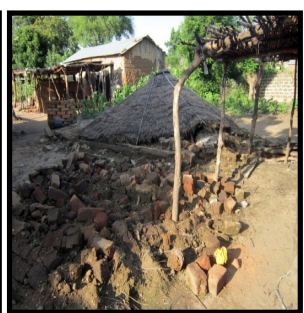

(b)

Figure 2. (a) Houses built on flood plains in Garoua; (b) Source: Collapse mud houses following floods in Garoua in 2012. Pictures courtesy of Plan International.

houses have been built with mud and sticks that easily collapse when flooded (see Figure 2(b)). Consequently, the houses are easily flooded even with low water-level rises after heavy rains. The inability to live in a safe area, and construct resilient houses, is directly linked to poverty and limited access to resources [8].

Another component of Biophysical vulnerability in Garoua is the hydraulic infrastructure. To boost the economy of the region-by generating electricity and irrigating the extensive rice fields in the lower Benue valley - the government, aided by the Chinese, constructed the Lagdo Dam $80 \mathrm{kms}$ South of Garoua along the Benue River from 1977-1982 [23]. The dam, which is 208 metres long, 40 metres high and 9 metres wide, has been deteriorating over recent years and is now a major contributor to flooding in Garoua [41]. High sedimentation rates, and high flood levels, have caused several structural defects on the hydraulic infrastructure [42]. Interviewees argue that the lack of maintenance funds has resulted in the irregular and poor management of the dam. For fear of structural failure, the dam's water is often released during heavy rainfall, flooding downstream areas around Garoua [28].

\subsection{Flood Impact in Garoua and Environs}

Repeated flooding in Garoua and North Cameroon seriously affects livelihoods and the economy of the region-causing deaths, destroying infrastructure such as bridges, roads, and houses, damaging farms and crops, and threatening the safety of critical infrastructure (see Table 1). The 2012 floods that hit Garoua have been analyzed here to show how a single flooding can be a threat to the social, economic and environmental security of the region.

After heavy and prolonged rainfall in Garoua (starting on August 15, 2012), River Benue and its tributaries overflowed, and inundated residential, agricultural, and industrial areas [25] [28]. The Lagdo dam exceeded its high water level and was fractured, forcing the decision to release excess water to prevent the dam from complete collapse [26] [41]. This inundation exacerbated the flooding downstream; right into Nigeria. According to Cameroon's DCP, the 2012 floods were the worst in Cameroon for more than 60 years and caused considerable damage and destruction. The flooding caused the deaths of more than 30 people in Garoua, and displaced a further 60,000. In addition, another 25,000 to 30,000 
people suffered general economic impacts from the disaster and with many others affected by a cholera and measles outbreak in the region. Bridges, homes, crops in the field and food stocks were damaged. Electricity generating infrastructure was damaged leading to power outages affecting thousands of homes. Infrastructural and agricultural damage has been estimated at billions of CFA francs. In addition, the flooding disrupted the smooth reopening of the 2012/ 2013 school year in Garoua because some school premises were used to host displaced people whilst others were flooded [25] [26] [28] [37] [43]. If a single flooding event can impact in such a way, then the cumulative impact of many such floods can set back development in the region for decades. That is why the government should take urgent action to enhance the resilience of the population and implement adequate structural measures to mitigate the impact of flooding in North Cameroon.

\subsection{Flood Management in Cameroon}

Although Cameroon has adopted the Sendai Framework for Disaster Risk Reduction, (that stresses the need for governments to invest in DRR for resilience) [2], natural hazard management in the country is still in need of considerable development. This section briefly analyses the legislative and institutional framework for flood management in Cameroon.

Respondents identified a number of shortcomings within the current legislative framework that may be hindering effective flood management in Cameroon. Disaster managers already admit that the legislative framework focuses only on flood response rather than a comprehensive flood DRR strategy. They also highlighted a weak incorporation of disaster mitigation and preparedness into existing legislation. In addition, they stated that no clear plan currently exists, within the legislative framework, to empower local government to address existing disaster risks, and thereby enhance local capacity structures to effectively deal with floods [44]. This often leads to a more reactive, rather than proactive, flood risk management culture; despite the high frequency of flooding in the country. Moreover, legislative provisions that do exist are perceived as being rarely enacted. For example, Law No. 037/PM of 19 March 2003 created a National Risks Observatory to identify the high-risk regions in the country [45]. However, a senior disaster manager remarked that the mapping of risk zones in Cameroon is "still in its infancy".

Respondents also drew attention to a lack of funding for natural hazard management as a key limitation to effective flood management. Since the legislative framework does not clearly provide for the establishment of effective budgetary provisions for the DCP [45] there are no funds for flood risk reduction, including the maintenance of hydraulic infrastructures. One interviewee remarked that this could be the reason why the Lagdo Dam has not been properly maintained over the years. Even funds for disaster emergency assistance appear only to be available on an ad hoc basis, during a crisis, and have to be approved and dis- 
bursed from the national government level [13] [45].

The organizational and administrative framework of any national governance is inevitably in part responsible for any subsequent inadequate flood management. In Cameroon, civil administrators, who act as chief disaster managers in their areas of jurisdiction at the national, regional and local levels, frequently do not have the necessary disaster management training or skills. Compounded by a hierarchical top-down power structure for the governance of disaster risks, such personnel will inevitably struggle to manage flood risks [44] [45].

Another concern raised by disaster managers, is the lack of multi-agency cooperation and collaboration in flood management. The DCP does not provide effective coordination and de-confliction of multiple government ministries with varied and sometimes conflicting interests in flood management [46]. Respondents who informed this research stated that this often leads to confusion and the duplication of functions during a flood crisis. This included a waste of scarce resources when multiple ministries were involved in the same activity (such as a flood impact appraisal, as was the case during the management of the 2012 floods in North Cameroon) [25] [26].

A crucial aspect of flood management is the monitoring and early warning for flood hazard mitigation, which respondents said are still very weak in Cameroon. Most rivers in Cameroon are not gauged and therefore information remains unavailable on water levels in the drainage systems. A comprehensive flood early warning system was not available prior to the devastating 2012 floods [41]. This highlights the problem of crisis communication deficiencies in DM arrangements in Cameroon, despite the country being characterized by a high frequency of hazards [47]. These factors underline the argument that poor disaster management is contributing to vulnerability to flooding.

\section{Discussion and Conclusion}

Using the "Hazard of Place" model of vulnerability, this article has critically analyzed the threat posed by repeated flooding to human, social and economic security in North Cameroon. The findings reveal that North Cameroon is vulnerable to flooding due to the interaction between environmental, geomorphic/ geographic and socio-economic conditions prevailing in the region. Although $\mathrm{CC}$ is a global phenomenon, $\mathrm{CV}$ is causing more rainfall, leading to an increase in the frequency of floods. Excessive water, even in arid Northern Cameroon, has demonstrated that flooding is less of a blessing, and more of a demonstration of the limitations of national and local social and economic security.

Findings on social vulnerability reveal that there is a high incidence of poverty in North Cameroon, with most of the inhabitants subsisting on rain-fed agriculture, although ironically, too much water is a threat to their agrarian livelihoods. Damages to agricultural lands increase hunger and poverty, which in turn limits the ability of the people to cope with, and respond to floods [8]. When floods strike repeatedly, damaging crops and killing livestock, the population suffers 
severely. With continuous damage to their livelihoods, there is a risk that the population can be trapped in a vicious cycle of poverty if urgent measures are not taken to mitigate the situation.

The results also reveal that the effects of flooding often translate into the prevalence of water borne diseases and health defects such as malnutrition. With limited access to health care, resulting in high fatalities, human capital is seriously affected, diminishing the quantity and quality of human capital available for DRR activities. Moreover, efforts to treat the diseases are diverting limited funds that could be used to adapt or mitigate floods. Another finding is that the large number of affected/displaced people during flood events distorts social networks, a useful resource that local communities use to get assistance.

Analyses of physical vulnerability have revealed locational choices for settlement in flood prone areas and houses built poorly, with weak construction materials. The consequence is that these houses, and their occupants, easily succumb even to the mildest floods. The research also found that the population and environment are at the mercy of the hydraulic infrastructures, which are fragile due to lack of maintenance and can easily be breached.

The findings have revealed that the region is prone to annual floods that occur over a very short period and whose impact may go unnoticed. The floodwaters damage roads and bridges disrupting transportation and communication, degrading the regional economy of the region, with funds that could be used to enhance flood risk reduction being diverted to repair work. We argue that regular damage of property and disruption of economic activities implies the population may not have time to recover. Consequently, the impacts may have longlasting effects on the affected population and the cumulative effects of flooding can set back economic development, keeping the populations in a permanent poverty trap. With climate forecasts predicting even worse future weather shocks, with increasing temperatures, long term damage to livelihoods and higher fatalities may place the 'at risk' population into a vicious cycle of destitution and poverty.

The management of flood risks in the country has unveiled legislative and institutional limitations, issues of poor governance of disaster risks, budgetary constraints and insufficient implementation of physical risk reduction measures; all of which handicap effective flood management in the country. Although CV is a contemporary phenomenon, its associated hazards like floods need not lead to disasters and a threat to human security in North Cameroon. However, this threat may well materialize if a robust and strategic approach is not put in place to mitigate social/physical vulnerabilities and enhance effective flood risk management in the country.

The findings of this paper will contribute to the literature on flooding and flood impacts in developing countries and open avenues for further flood research in dryland environments especially with a focus to mitigate their potentially dire effects. 


\section{References}

[1] CRED/UNISDR (2016) The Human Cost of Weather Related Disasters 1995-2015. https://www.unisdr.org/2015/docs/climatechange/COP21_WeatherDisastersReport 2015_FINAL.pdf

[2] UNISDR (2015) Sendai Framework for Disaster Risk Reduction 2015-2030. http://www.unisdr.org/files/43291_sendaiframeworkfordrren.pdf

[3] IFRC (2015) World Disaster Report: Focus on Local Actors, the Key to Humanitarian Effectiveness.

https://ifrc-media.org/interactive/wp-content/uploads/2015/09/1293600-World-Dis asters-Report-2015_en.pdf

[4] FAO (2016) FAO in the 2016 Sahel Humanitarian Appeal. http://www.fao.org/emergencies/appeals/detail/en/c/383968/

[5] IPCC (2014) Impacts, Adaptations and Vulnerability, Fifth Assessment Report. http://www.ipcc.ch/report/ar5/wg2

[6] Guha-Sapir, D., Below, R. and Hoyois, P. (2016) EM-DAT: The CRED/OFDA International Disaster Database Université Catholique de Louvain, Belgium. http://www.emdat.be

[7] Bang, H. (2016) Thirty Years after the Lake Nyos Disaster, What Prospects for Rehabilitation and Reintegration in the Region? Disaster Management, Risk Perception, Social Vulnerability and Relocation Decisions in Cameroon. Book Venture Publishing, Michigan, USA.

[8] Wisner, B., Blaikie, P., Cannon, T. and Davis, I. (2004) At Risk: Natural Hazards, People's Vulnerability and Disasters. 2nd Edition, Routledge, London.

[9] Cutter, S. (1996) Vulnerability to Environmental Hazards. Human Geography, 20, 529-539. https://doi.org/10.1177/030913259602000407

[10] Cutter, S., Boruff, B. and Shirley, W. (2003) Social Vulnerability to Environmental Hazards. Social Science Quarterly, 84, 242-261. https://doi.org/10.1111/1540-6237.8402002

[11] Molua, E. and Lambi, C. (2007) The Economic Impact of Climate Change on Agriculture in Cameroon. Policy Research Article. https://doi.org/10.1596/1813-9450-4364

[12] McSweeney, C., New, M. and Lizcano, G. (2012) UNDP CC Profiles, Cameroon. http://www.geog.ox.ac.uk/research/climate/projects/undp-cp/index.html?country= Cameroon\&d1=Reports

[13] Balgah, R., Buchenrieder, G. and Mbue, N. (2015) When Nature Frowns: A Comprehensive Impact assessment of the 2012 Babessi Floods on People's Livelihoods in Rural Cameroon. Jàmbá: Journal of Disaster Risk Studies, 7, 8 p. https://doi.org/10.4102/jamba.v7i1.197

[14] Ndille, R. and Belle, J. (2014) Managing the Limbe Floods: Considerations for Disaster Risk Reduction in Cameroon. International Journal of Disaster Risk Science, 2, 147-156. https://doi.org/10.1007/s13753-014-0019-0

[15] Ayonghe, S., Ntasin, B., Samalang, P. and Suh, E. (2004) The June 27, 2001 Landslide on Volcanic cones in Limbe, Mount Cameroon, West Africa. Journal of African Earth Sciences, 39, 435-439. https://doi.org/10.1016/j.jafrearsci.2004.07.022

[16] Molua, E. (2012) Gendered Response and Risk-Coping Capacity to Climate Variability for Sustained Food Security in Northern Cameroon. International Journal of Climate Change Strategies and Management, 3, 277-307. 
https://doi.org/10.1108/17568691211248739

[17] Yin, R.K. (2003) Case Study Research Design and Methods. Thousand Oaks, Sage, California.

[18] Stake, R.E. (2000) Case Studies. In: Denzin and Lincoln, Eds., The Handbook of Qualitative Research, Sage Publications Inc.

[19] Bhattacherjee, A. (2012) Social Science Research: Principles, Methods, and Principles, Textbooks Collection. Book 3.

http://scholarcommons.usf.edu/oa_textbooks/3

[20] WFP (2016) What Are the Current Issues in Cameroon. https://www.wfp.org/countries/Cameroon

[21] Gergely, N. (2009) The Cotton Sector of Cameroon. Africa Region Working Article Series No. 126 March, USA: World Bank.

[22] MINADER (2014) Overview of the Status of Cameroonian Cotton (Crop Year 2012-2013). https://www.icac.org/wp-content/uploads/2012/07/Cameroon_E.pdf

[23] Tchotsoua, M., Aboubakar, M. and Fotsing, J.-M. (2008) The Socio-Economic Downstream Impact of Large Dams: A Case Study from an Evaluation of Flooding Risks in the Benue River Basin Downstream of the Lagdo Dam (Cameroon). Journal of African Studies, 1, 16-19.

[24] Tchindjang, M., Amougou, J., Abossolo, S. and Bell, S. (2012) Challenges of Climate Change, Landscape Dynamic and Environmental Risks in Cameroon. In: Runge, J., Ed., Landscape Evolution, Neotectonic and Quaternary Environmental Change in Southern Cameroon, Taylor and Francis Group, Boca Raton.

[25] Reliefweb (2012) Cameroon: Floods in the North and Far North Regions. DREF Operation No. MDRCD014.

http://reliefweb.int/map/cameroon/cameroon-floods-north-and-far-north-regionsdref-operation-n\%C2\%B0-mdrcd014

[26] UNICEF (2012) Flash floods in North Cameroon meet fast response from UNICEF Cameroon. http://www.unicef.org/wcaro/english/4501_7022.html

[27] DCP/ MTAD (2009) Cameroon Civil Protection Report, 2008/2009. Civil Defence Through Li fe Saving Actions, MTAD, Yaounde.

[28] IFRC (2012) Emergency Appeal Cameroon: Floods, Emergency Appeal No. MDRCM014. GLIDEFL-2012-000157-CMR 28 September 2012.

http://www.ifrc.org/docs/Appeals/12/MDRCM014ea.pdf

[29] United Nations International Strategy for Disaster Reduction (2015) Cameroon's Cities Tackle Flood Risk.. http://www.unisdr.org/archive/45366

[30] IMF (2010) Cameroon: Poverty Reduction Strategy Paper. https://www.imf.org/external/pubs/ft/scr/2010/cr10257.pdf

[31] Flink, J., Ziebe, R., Vagai, D., van de Looij, F., 'T Riet, V. and Houweling, T. (2016) Targeting the Poorest in a Performance-Based Financing Programme in Northern Cameroon. Health Policy and Planning, 31, 767-776. https://doi.org/10.1093/heapol/czv130

[32] National Institute of Statistics (NIS) (2016) Characteristics of the Population of Cameroon. https://knoema.com/atlas/sources/National-Institute-of-Statistics-Cameroon

[33] African Development Bang (2015) Cameroon: Joint 2015-2020 Country Strategy Paper and Country Portfolio Performance Review Report, June, 2015.

[34] Neba, C., Ngassam, S. and Nzomo, J. ( 2010) The Determinants of the Technical Ef- 
ficiency of Cotton Farmers in Northern Cameroon', MPRA Article No. 24814. http://mpra.ub.uni-muenchen.de/24814/

[35] Nkwi, W. (2013) Cameroon, Too Much to Carry: the Perception and Ramifications of Boko Haram's Activities on Cameroon. Conflict Studies Quarterly, 5, 67-87.

[36] UNICEF (2012) Flash Floods in North Cameroon Meet Fast Response from UNICEF Cameroon. http://www.unicef.org/wcaro/english/4501_7022.html

[37] CERF (2012) CERF Provides US\$2 Million for Flood-Affected People in Cameroon. http://www.unocha.org/cerf/cerf-worldwide/where-we-work/cmr-2012

[38] WHO (2014) Cameroon Country Cooperation Strategy at a Glance. http://apps.who.int/iris/bitstream/10665/137092/1/ccsbrief_cmr_en.pdf

[39] Cartwright, E., Patel, K., Mbopi-Keou, F., Ayers, T., Haenke, B., Wagenaar, B., Mintz, E. and Quick, R. (2013) Recurrent Epidemic Cholera with High Mortality in Cameroon: Persistent Challenges 40 Years into the Seventh Pandemic. Epidemiology and Infection, 141, 2083-2093. https://doi.org/10.1017/S0950268812002932

[40] Schneiderbauer, S. and Ehrlich, D. (2006) Risk, hazard and People's Vulnerability to Natural Hazards: A Review of Definitions, Concepts and Data. European Commission-Joint Research Centre (EC-JRC), Brussels.

[41] World Bank (2013) World Bank to Help Cameroon Recover from Major Floods and Resume Rice Production.

http://www.worldbank.org/en/news/press-release/2013/06/11/world-bank-help-cam eroon-recover-major-floods-resume-rice-production

[42] Saborío-Bejarano, J. and Mora-Castro, S. (2012) Evaluation de L'etat du Barrage, des Digues, du Reservoir et des Structures Hy-Drauliques du Systeme de Maga-Logone-Vrick. Situation Hydrolo gique, Geotechniqueet Menaces Naturelles, Rapport technique.

http://www.drrinacp.org/sites/drrinacp.org/files/publication/Cameroon_Technical_ evaluation_dam.pdf

[43] Ngalame, E. (2012) Cameroon: Government Urged to Reduce Disaster Risk after Northern Floods. All Africa News. http://allafrica.com/stories/201210260230.html?viewall=1

[44] Bang, H. (2013) Governance of Disaster Risk Reduction in Cameroon: the Need to Empower Local government. Jàmbá: Journal of Disaster Risk Studies, 5, 10 p. https://doi.org/10.4102/jamba.v5i2.77

[45] Bang, H. (2014) General Overview of the Disaster Management Framework in Cameroon. Disasters, 38, 562-586. https://doi.org/10.1111/disa.12061

[46] Sighomnou, D. (2005) Cameroon: Integrated Flood Management in River Logone Flood-Plain. http://www.apfm.info/publications/casestudies/cs_cameroon_syn.pdf

[47] Miles, L., Gordon, R. and Bang, H. (2017) Blaming Active Volcanoes or Active Volcanic blame? Volcanic Crisis Communication and Blame Management in the Cameroon. In: Fearnlay, C., Bird, D., Jolly, G., Haynes, K. and McGuire, B., Eds., Observing the World Volcanoes. https://link.springer.com/content/pdf/10.1007\%2F11157_2017_2.pdf 
Submit or recommend next manuscript to SCIRP and we will provide best service for you:

Accepting pre-submission inquiries through Email, Facebook, LinkedIn, Twitter, etc. A wide selection of journals (inclusive of 9 subjects, more than 200 journals)

Providing 24-hour high-quality service

User-friendly online submission system

Fair and swift peer-review system

Efficient typesetting and proofreading procedure

Display of the result of downloads and visits, as well as the number of cited articles Maximum dissemination of your research work

Submit your manuscript at: http://papersubmission.scirp.org/

Or contact wjet@scirp.org 